\title{
THE DEVELOPMENT OF FREE PRIMARY EDUCATION SCHEME IN WESTERN NIGERIA, 1952-1966: AN ANALYSIS
}

\section{Abstract}

\section{S. Ademola Ajayi}

In 1955, the government of Western Region of Nigeria introduced a free primary education programme. That scheme, which featured prominently up till 1966, suffered a major blow, following the military take-over of government in that year. Despite this, the scheme has left an indelible imprint in the annals of education in Western Nigeria and the whole country. Using both primary and secondary documents, this paper analyses the circumstances surrounding the introduction of this revolutionary scheme, as well as its historical development. The paper concludes with an examination of some of the impacts of the programme.

\section{Introduction}

The 1950s ushered in a revolutionary phase in the history of education in Nigeria. This period witnessed the introduction of Free Education scheme in Western Region and marked a radical departure from the hitherto existing educational patterns not only in Western Nigeria but the entire country. This pace-setting epoch, whose proposals were presented in 1952, was launched in January 1955. It was featured as a cardinal programme of the Action Group in Western Nigeria and continued to be the official policy of the Western Region government until 1966 when a military coup d'état suspended all political activities, and concomitantly, the programmes of the respective regional political parties existing then.

Although the Free Education programme commenced effectively in 1955 when it was launched, preparations for it had begun in 1952 when proposals for the scheme were tabled before the Western Region House of Assembly. This, therefore, is what informs our choice of 1952 as the take-off date in this paper. Our terminal date is 1966 because the military take-over of power in the country that year effectively stopped the scheme.

Western Nigeria-the focal point of this paper-consisted of eight provinces namely, Abeokuta, Benin, Colony (i.e. Lagos), Delta, Ibadan, Ijebu, Ondo, and Oyo. These were collectively known as the 
"western provinces", a term that was formally applied to the entire region in 1939 when the administration of the colony and protectorate of Southern Nigeria, created in 1906, was reorganized into two main groups of provinces-the Eastern and Western provinces respectively (Asiwaju 1980:429). This is the area covered by the former Western, Mid-Western and parts of Lagos States respectively, and the present-day Oyo, Ogun, Ondo, Ekiti, Osun, Lagos, Edo and Delta States.

\section{Purpose of the Study}

The issue of Free Primary Education scheme in Western Nigeria is very topical. Thus, it has been a perennial theme in some academic symposia, lectures, debates, reputable journals and standard textbooks. However, there are still some salient issues concerning the scheme that have not been exhaustively and objectively discussed.

Therefore, the purpose of this paper is to investigate the issues relating to the development of the Free Primary Education scheme in the region between 1952 and 1966. This is with a view to highlighting the socio-cultural, economic, historical and political prelude to the scheme. Also, the study is to highlight the features of the scheme in terms of establishment of schools, rise in pupils' enrolment and government support for the scheme in terms of budgetary allocation. The study also examines the pitfalls of the scheme as well as its strengths.

Specifically, an attempt is made to answer the following research questions in the study:

i. What were the features of the Free Primary Education programme in Western Nigeria?

ii. What constitute the socio-cultural, economic, historical and political prelude to the scheme?

iii. How was the scheme launched and implemented?

iv. Did the scheme face any obstacles?

v. What were/are the benefits and impact of the scheme?

\section{Prelude to the Introduction of Free Education}

It is common knowledge that the Christian Missionaries pioneered western education in Western Nigeria in particular and 
Nigeria in general. The missionaries' efforts were, in the course of time, complemented by the British colonial administration. By the mid-twentieth century, therefore, it could be rightly asserted that the Western form of literary education had, to some extent, been firmly rooted in Western Nigeria-thanks to the joint effort of the various Christian Missions and the colonial government. However, because of the limited objectives of the pioneers of Western Education in Nigeria, educational development in Western Nigeria as was the case in the entire country in the period before 1950 was grossly inadequate for meeting the needs of a modern state. The missions in the South were interested in education as an instrument of evangelization, while the colonial administration saw the schools as agencies for producing various categories of minor functionaries (such as clerks, junior technicians in public works, sanitary inspectors etc).

For Nigeria, the decade of the 1950s was marked by the crucial transition from colonial to independent status (Abernethy 1952:125). In 1951, the country adopted a Federal Constitution named after its author-Sir John Macpherson. Through its provisions, the regional Houses of Assembly ceased to be potent advisory bodies for which they had been noted since their formation in 1946. Henceforth, the new constitution provided for democratic election to the regional Houses of Assembly. But, more importantly, the legislature of each region was empowered to make laws for peace, order and good government of the region, with respect to certain enumerated subjects, of which education was one (Macpherson Constitution 1951; Section 92). With this new development, therefore, responsibility for education devolved on the governments of the regions. Consequently, ministries of education were created in each of the Regions of Nigeria, and were responsible for education in their respective regions, while the Federal Ministry of Education was in charge of Education in the Federal Territory of Lagos.

The Action Group Party led by Chief Obafemi Awolowo, won the first election to the Western House of Assembly in 1952. In his first budget speech, Chief Awolowo (who functioned then as the Regional Minister for Local Government and as well the unofficial Leader of Government Business) made it clear to the members of the House that his government would give top priority to education, 
among other things, as far as that budget would allow. He spelt this out as a basic principle by which his party was to be guided. "As he stressed in later years, "as far as possible, expenditure on services which tend to the welfare and health and education of the people should be increased at the expense of any expenditure that does not answer to the same test" (Awolowo 1960:263).

In July of the same year (1952), the Minister of Education for the Western Region, Chief S. O. Awokoya, presented a comprehensive set of proposals calling for a free, universal and compulsory education otherwise known as the Universal Primary Education (U.P.E.) for the Western Region by January 1955 (Awokoya'a Proposal 1952). To make such a programme possible without lowering standards drastically, the minister included in his proposal a massive teacher-training programme, the expansion of teacher training facilities and secondary schools, the introduction of secondary technical education and Secondary Modern school (Western House of Assembly Debates: 30 July 1952). This was the prelude to the birth of what Babs Fafunwa (1974:168) has described as "the boldest and perhaps the most unprecedented educational scheme in Africa South of the Sahara" as an ample demonstration of the Western Regional government's whole-hearted commitment to the vital interest of her subjects.

\section{The Launching and Implementation of the Scheme}

With the introduction of Awokoya's proposal, the Western Nigerian government began to make a series of preparations from July 1952 to December 1954 to meet the January 1955 deadline. Among other measures, there was a massive teacher-training programme put in place to complement the existing one. Similarly, facilities for secondary schools were expanded while the pre-1955 period also witnessed the introduction of secondary technical education and secondary modern schools.

As planned by the government, the Free Education scheme was formally introduced on 17 January, 1955. "The launching of this scheme", says Fajana (1978:238), "was a milestone in the educational history of Nigeria." A remarkable feature of the educational reform of this era was the rapid numerical growth of schools at all levels-primary, secondary (modern and grammar) as 
well as tertiary. Teacher training institutions were equally expanded, all with the aim of translating the proposal of the government into reality.

The greatest expansion of this period was at the primary school level. Thus, the number of primary schools rose from 3,550 in 1952 to 6,274 by the end of 1954 (Taiwo 1978:116). By 1955, the figure had risen to 6,407 (see Table 1). By the end of 1958, the number of primary schools had risen as high as 6,670. The general trend of expansion of primary and post-primary schools is well illustrated in Table 1 below

TABLE 1

NUMBER OF SCHOOLS IN THE WESTERN REGION BY TYPE 1954 - 60

Type of School

Primary

Secondary Modern

Secondary Grammar

Grade III Teacher Training

Grade II Teacher Training

Vocational Schools

\begin{tabular}{|c|c|c|c|c|c|}
\hline 19541955 & 1956 & 1957 & 1958 & 1959 & 1960 \\
\hline$-\ldots \quad 6,407$ & 6,603 & 6,628 & 6,670 & 6,518 & 6,450 \\
\hline 180 & $106+$ & 254 & 262 & 420 & 533 \\
\hline 73 & 91 & 108 & 117 & 138 & 167 \\
\hline 59 & 69 & 71 & 70\# & 67 & 69 \\
\hline 25 & 27 & 27 & 28 & 30 & 31 \\
\hline-- & -- & 2 & 2 & 2 & 5 \\
\hline
\end{tabular}

Note:* Accurate figures not known

+ Reduction in 1955 figure due to consolidation of number of school.

\# Grade III programme at Baptist, Idi-Aba closed and students moved to Baptist, Ife.

Source: Computed from Western Region of Nigeria, Annual Abstract of Education Statistics, 1953-58 \& 1955-60 respectively. (Ibadan: Ministry of Economic Planning and Community Development. Statistics Division, June 1959 \& September 1961 respectively p. 7)

Table 2

Number of Schools in the Western Region by Type 1961-66

\begin{tabular}{|c|c|c|c|c|c|c|}
\hline Type of School & 1961 & 1962 & 1963 & 1964 & 1965 & 1966 \\
\hline Primary & 6,468 & 6,420 & 6,311 & 4,375 & 4,364 & 4,340 \\
\hline Secondary Mod. & 586 & 666 & 699 & 459 & 441 & 394 \\
\hline Sec Grammar & 177 & 189 & 212 & 174 & 195 & 206 \\
\hline Grade III T. T. & 69 & 69 & 53 & 38 & -- & --- \\
\hline Grade II T. T. & 33 & 36 & 35 & 30 & 33 & 31 \\
\hline G. I (Rural Sc)T.T. & --- & --- & 1 & 1 & 1 & --- \\
\hline Advanced T. T & --- & $\ldots$ & 2 & 3 & 2 & 2 \\
\hline Voc. Schools & 4 & 5 & $5^{*}$ & 5 & 5 & 5 \\
\hline Junior Schools & --- & --- & --- & --- & 6 & 6 \\
\hline Tech Institutes & --- & --- & - & 1 & 1 & 1 \\
\hline Sch for Handicpd & --- & --- & 2 & 3 & 3 & 3 \\
\hline Special Schools & -- & --- & --- & ---- & --- & 23 \\
\hline
\end{tabular}

* Excluding Trade Centre, Sapele 
Source: Computed from Western Nigeria, Annual Abstract of Education Statistics, 1961-1966 (Ibadan: Ministry of Economic Planning and Community (later Social) Development. (Statistics Division, 1961-67).

In 1963, the Mid-West Region was carved out of the old Western Region. This explains why there was a reduction in the number of schools thereafter (compare the 1963 and 1964 figures above). Following the creation of the Mid-West, therefore, the Statistics Division of the Ministry of Economic Planning and Community Development prepared a new statistics, details of which are provided by this writer elsewhere (Ajayi 1984:48).

Even though the real intention of the government was to provide free primary education for all eligible pupils, the tables above show that the development of the scheme was not limited to this level of education. In practical terms, primary education was not developed in isolation. It was viewed as a means to an end and not as an end in itself. Thus, other levels of education were seen as part and parcel of the whole scheme. As one is handicapped by space limitation in this paper, the reader who may be interested in the overall development of the scheme especially as it affects these other levels would benefit from the comprehensive analysis by this writer in an earlier work (Ajayi 1984).

Be that as it may, one of the most significant features of the era was the rapid growth in school population at all levels. In 1952 when Awokoya presented his historic proposal before the Western House of Assembly, the number of children at school in the region then was 381,000 . The total number of children of school age by then was estimated at 1,146,000 (Awokoya 1952: 17). Going by that estimate, the number of children not at school, therefore, was about 765,000 or 66.75 per cent of children of school age.

During the first six years of Free Universal Primary Education, there were increases in both boys' and girls' enrolment. This was to be expected though not to the extent to which it did occur. In the 1954 school year, 456,600 pupils were attending primary schools in Western Nigeria but when the scheme was launched in 1955 January, 811,432 children turned up (see Table 3), making an increase of 354, 832 over the figure of the enrolment for the previous year. These figures represented a jump from 35 per cent to 63 
percent of the 5-14 year-old (Fafunwa 1974:168). The same table (3) shows that by 1958 , over one million children were enrolled.

Table 3

Enrolment in Primary Schools in the Western Region by Sex, 1953 - 1960

$\begin{array}{cccclc}\text { Year } & \text { Boys } & \text { Girls } & \text { Total } & \text { Inc Over Previous Yr } & \text { \% Change } \\ 1953 & 320,542 & 109,000 & 429,542 & ---- & --- \\ 1954 & 340,610 & 115,990 & 456,600 & 27,058 & 6.30 \\ 1955 & 536,676 & 274,756 & 811,432 & 354,832 & 77.71 \\ 1956 & 583,688 & 324,334 & 908,022 & 96,590 & 11.90 \\ 1957 & 619,577 & 363,178 & 982,755 & 74,733 & 8.23 \\ 1958 & 642,856 & 394,532 & 1,037,388 & 54,644 & 5.56 \\ 1959 & 665,442 & 414,861 & 1,080,303 & 42,915 & 4.14 \\ 1960 & 687,215 & 437,573 & 1,124,788 & 44,485 & 4.12 \\ 1961 & 677,009 & 454,400 & 1,131,409 & 6,621 & 0.59 \\ 1962 & 656,551 & 454,448 & 1,109,999 & -22,410 \text { (decrease) } & -1.98 \\ 1963(\text { a) } & 643,826 & 455,592 & 1,099,418 & -9,581 \text { (decrease) } & -0.86 \\ \text { “ } & \text { (b)(433,075) } & (296,472) & (729,547) & -6,776 \text { (decrease) } & -0.62 \\ 1964 & 435,399 & 297,771 & 733,170 & 3,623 & -0.50 \\ 1965 & 438,184 & 298,964 & 737,148 & 3,978 & -0.54 \\ 1966 & 440,991 & 300,006 & 740,997 & 3,849 & -0.52\end{array}$

* N. B. Figures in bracket are the new ones prepared by the Statistics Division of the Ministry of Economic Planning and Community Development after the carving out of the Mid-West region in 1963.

Source: Computed from Western Nigeria Annual Abstract of Education Statistics 1954-66 (Ibadan, Ministry of Economic Planning and Community Development, Statistics Division)

The greater increase of girls over boys could be explained by the fact that the introduction of free primary education must have changed the attitude of parents towards the education of girls. Hitherto, it used to be argued that the place of the woman was in the home and that any scholastic training was going to be "wasted" eventually in the kitchen. With the new wind of change and the concomitant change in perception, therefore, the proportion changed from 5 boys to 1 girl in 1954 to about 5 boys to 2 girls in 1955. The number of girls in school more than doubled between these two years (1954 and 1955) as could be seen in Table 3. This new development could be explained in terms of the fact that parents did not have to spend money on school fees, and therefore felt that they had nothing to lose by sending their female children to school.

Be that as it may, 1961-66 shows, in contrast to the preceding phase, that there was a decrease in the enrolment of boys and a greatly reduced increase in the case of the girls. Here it should be noted that the previous $1955-60$ period was the first complete school generation under the policy of free primary education. Consequently, 
as one might expect, the number of school leavers coming out of school from 1960-66 was bound to be in excess of job opportunities available for children with only a primary school education. This produced a trend in which parents were tending not to send their children to school but to keep them on the farm as part of the family labour. Another possible cause for the decrease could be explained in terms of the government's policy of merger of schools in 1962 due to enrolment wastage and other logistic problems, details of which are highlighted in Ajayi (1984: 112-132).

\section{Regional Budgetary Allocation and Government Expenditure on Education}

Between 1954 and 1966, education attracted the largest share of the Western Region's recurrent budget, having varied between 28.9 per cent and 41.2 per cent during the period (Table 4). In the 195859 financial year, for instance, 41.2 percent of the total recurrent budget was devoted to education alone. This, undoubtedly, represented one of the highest proportional expenditures on education, the world over. That was an ample demonstration of the great importance that the regional government placed on education. However, the fact should equally not be ignored that the more money spent on education, the less there was for the sectors that could provide employment and other services.

Table 4

Comparison of Recurrent Educ. Budget with the Regional Budget, 1954 - 66

\begin{tabular}{|l|c|c|c|}
\hline Year & $\begin{array}{c}\text { Actual } \\
\text { Education } \\
\text { Recurrent Budget } ₹\end{array}$ & $\begin{array}{c}\text { Actual } \\
\text { Regional Recurrent } \\
\text { Budget £ }\end{array}$ & $\begin{array}{c}\text { Education as } \\
\text { \% of Regional }\end{array}$ \\
\hline $1954-55$ & $3,806,745$ & $9,283,690$ & 41.0 \\
\hline $1955-56$ & $3,873,305$ & $11,366,931$ & 34.0 \\
\hline $1956-57$ & $4,496,201$ & $15,522,128$ & 28.9 \\
\hline $1957-58$ & $5,506,880$ & $14,288,000$ & 38.5 \\
\hline $1958-59$ & $5,616,687$ & $13,604,163$ & 41.2 \\
\hline $1959-60$ & $7,161,303$ & $22,152,351$ & 32.3 \\
\hline $1960-61$ & $8,773,325$ & $22,769,880$ & 38.5 \\
\hline $1961-62$ & $8,548,829$ & $21,798,923$ & 39.2 \\
\hline $1962-63$ & $8,891,921$ & $24,948,913$ & 35.6 \\
\hline $1963-64$ & $6,206,949$ & $18,191,071$ & 34.1 \\
\hline$* 1964-65$ & $6,554,640$ & $16,946,310$ & 38.6 \\
\hline$* 1965-66$ & $7,048,530$ & $19,861,290$ & 35.4 \\
\hline
\end{tabular}


*Government Approved Estimated Expenditure.

Source: Some Trends in Education in the Western Region of Nigeria 1955 - 65 (Pilot Project for Rural Employment Promotion (International Labour Office Mission, Ibadan, Western Nigeria, October 1965) p. 17

The lion share of the budget for education at that time went to primary education alone. Table 5 shows the huge percentage that primary education alone consumed from the total government grants to educational institutions. The percentage varied from 52 in 1955 to 84 in 1960 after which it never went below 74 per cent. In the 1955 school year alone, $£ 2.14$ million was spent on the construction of primary school buildings, and between 1954 and 1958 about \#5 million was spent for this same purpose (Annual Report 1954-55 :24)

Table 5

Western Regional Government of Nigeria, Grants to Primary Educational Institutions, $1955-66$

\begin{tabular}{|c|c|c|c|}
\hline Year & $\begin{array}{l}\text { Grants to Primary } \\
\text { Education }\end{array}$ & $\begin{array}{l}\text { Total Grants to } \\
\text { Education }\end{array}$ & $\begin{array}{l}\text { Percentage of } \\
\text { Grants to Primary } \\
\text { Education }\end{array}$ \\
\hline & $' 000{ }^{\prime} £ \mathrm{~s}$ & $' 000{ }^{\prime} £ \mathrm{~s}$ & $\%$ \\
\hline $1955-56$ & $2,767,000$ & $5,342,000$ & 52 \\
\hline $1956-57$ & $3,011,000$ & $5,059,000$ & 60 \\
\hline $1957-58$ & $3,337,000$ & $5,885,000$ & 57 \\
\hline $1958-59$ & $3,867,000$ & $5,569,000$ & 69 \\
\hline $1959-60$ & $4,883,000$ & $5,889,000$ & 82 \\
\hline $1960-61$ & $6,205,000$ & $7,400,000$ & 84 \\
\hline $1961-62$ & $6,144,000$ & $7,566,000$ & 81 \\
\hline $1962-63$ & $5,944,000$ & $7,850,000$ & 76 \\
\hline $1963-64$ & $4,551,000$ & $6,170,000$ & 74 \\
\hline $1964-65$ & $4,791,000$ & $6,178,000$ & 78 \\
\hline $1965-66$ & $5,020,000$ & $6,250,000$ & 80 \\
\hline
\end{tabular}

Source: $\quad$ Compiled from Western Nigeria Annual Abstract of Education Statistics, 1955-66 (Ibadan: Government Printer). 


\section{Conclusion}

Examining an educational system in order to appraise its contribution to social development entails a system analysis of education itself. Education is not just an end in itself but a means to an end. There is the universal acceptance of education as a form of investment in human beings which yields economic benefits or returns and "contributes to a nation's future wealth and development by increasing the productive and consumptive capacity of its citizens" (Nwagwu 1976:111). Viewed in this way, all expenditures on education can, to a great extent, be justified in terms of the potential contribution of education to economic growth and overall national development. In a nutshell, therefore, the Free Primary Education scheme in Western Nigeria in the period 1952-1966 should be seen as a form of social and economic investment, the benefits of which seem to justify the enormous sums of money spent on it. Some of these benefits are discussed below.

Commenting on the education venture of the Western Regional Government during the 1950s, Richard Sklar (1963:419) remarked: "Possibly no single decision of the decade prior to independence had been more fateful for the development of the political economy of Nigeria". The scheme was indeed an epoch-making event, which quantitatively represents a very impressive achievement. With over 50 percent of children between the ages of six and twelve years as beneficiaries, the region took a big stride towards the goal of universal primary education. The phenomenal increase in primary school enrolments throughout the entire duration of the scheme, no doubt, brought positive advantages. Among other things, it provided a wider base from which the secondary schools, trade schools and teacher training colleges drew their new entrants. This in turn quickened the pace of the development of middle-level manpower. The institutions of higher education also benefited. So did the labour market and the economy. On the basis of the above, it follows that a growing proportion of the population of Western Nigeria was likely to make better materials for modernization.

An equally significant development associated with free primary education was the inculcation in parents, of the need for female education and the concomitant higher proportion of girls who benefited from the scheme. Thus, the era broke the myth and 
indifference towards female education (Ajayi 1984:149). Throughout the era, there was a phenomenal increase in the number of girls being educated in schools. In contrast to 1954 when one out of five pupils in primary school was a girl, for example, by 1966, almost two out of five were girls. These figures are indicative of a more enlightened attitude to the education of women, which was bound to pay off in terms of nation-building in the medium and long run. In educating more girls, a larger pool of talent and potential manpower was obviously tapped. The investment in the education of increasing numbers of future mothers has paid rich dividends. Today, most of the beneficiaries are parents who have had an improved basis on which to evaluate the education their children receive.

Although the Free Primary Education scheme was not without certain inherent problems and adverse consequences, such as high wastage rate, falling standards (arising largely from inadequate number of teachers as well as automatic promotion of pupils to the next class), unemployment and the like, these should be viewed as natural consequences of any ambitious and revolutionary programme such as free primary education.

On a final note, there is no gainsaying the fact that the Free Primary Education scheme in Western Nigeria made a considerably remarkable impact and left an indelible imprint in the history of education in Western Nigeria and the country as a whole, an example which, to some extent, was followed in 1976 by the federal government of Nigeria. 


\section{References}

Abernethy, D. B. (1969) The Political Dilemma of Popular Education - An African Case (Stanford: Stanford University Press).

Adesina, S. (1977) Planning and Educational Development in Nigeria (Lagos, Educational Industries Nigeria Ltd.)

Ajayi, S. Ademola (1984) "The Development of Free Education in Western Nigeria, 1951-1966: An Historical Analysis". Unpublished MA Dissertation, Department of History, University of Ibadan, Ibadan, Nigeria, Ajayi, S. Ademola (2008). "The Genesis of Free Education in Western Nigeria, 1951-1966." in Journal of Social Sciences Vol 3 No 1. (Faisalabad: Government College University) pp. 108-122

Awokoya, S.O. (1952). Proposals for an Education Policy for the Western Region of Nigeria (Laid on the Tables of the Western Regional Legislature by the Minister of Education). Ibadan, Government Printer.

Awolowo, O. (1960) Awo: The Autobiography of Chief Obafemi Awolowo (Cambridge: Cambridge University Press).

Asiwaju, A.I. (1980). "The Western Provinces under Colonial Rule" in Obaro Ikime (ed) Groundwork of Nigerian History (Ibadan: Heinemann)

Fafunwa, A. B. (1974) History of Education in Nigeria (London: George Allen \& Unwin,)

Fajana, A. (1978) Education in Nigeria, 1942 - 1939: An Historical Analysis (Ikeja: Longman).

Government of the Western Region of Nigeria (1966). Progress in Western Nigeria- Education (A Ministry of Information Production, Western Nigeria, 1966). Ibadan: Government Printer.

Nwagwu, N.A. (1976). Universal Primary Education in Nigeria: Issues, Prospect and Problems. (Benin- City: Ethiope Publishing Corporation).

Sklar, R.C.(1963) Nigerian Political Parties : Power in an Emergent African Nation. Princeton, NJ: Princeton University Press

Some Trends in Education in the Western Region of Nigeria, 1955-65. (Pilot Project for Rural Employment Promotion) International Labour Office Mission, Ibadan, Western Nigeria. (Ibadan, 9 October, 1965).

Taiwo, C. O. (1980) The Nigerian Education System: Past, Present \& Future (Ikeja: Thomas Nelson).

Taiwo, C.O.(1968) Report of the Committee on the Review of the Primary Education System in the Western State of Nigeria.

Western House of Assembly (1952). Official Report of the House Debates of $30^{\text {th }}$ July. (Ibadan: Government Printer).

Western Nigeria Government, Education Laws (1955) Ibadan: Government Printer 